\title{
Adipose-derived mesenchymal stem cells (ASCs) transplantation restored olfactory function in anosmic rats
}

\author{
Bijan Khademi ${ }^{1,2}$, Zohreh Zandifar ${ }^{2}$, Ahmad Monabati ${ }^{3}$, Nooshafarin Chenari ${ }^{4}$, Abbas Ghaderi ${ }^{4,5}$, \\ Mahboobeh Razmkhah ${ }^{4}$ \\ ${ }^{1}$ Research Center of Otolaryngology Head and Neck Surgery, Shiraz University of Medical Sciences, Shiraz, Iran \\ ${ }^{2}$ Department of Otorhinolaryngology, Shiraz University of Medical Sciences, Shiraz, Iran \\ ${ }^{3}$ Department of Pathology, School of Medicine, Shiraz University of Medical Sciences, Shiraz, Iran \\ ${ }^{4}$ Shiraz Institute for Cancer Research, School of Medicine, Shiraz University of Medical Sciences, Shiraz, Iran \\ ${ }^{5}$ Department of Immunology, School of Medicine, Shiraz University of Medical Sciences, Shiraz, Iran
}

\begin{abstract}
Dr. Mahboobeh Razmkhah, Shiraz Institute for Cancer
Research, Shiraz University of Medical Sciences, Shiraz, Iran, PO BOX: 71345-1798.
\end{abstract}

Citation: Khademi B, Zandifar Z, Monabati A et al. Adipose-derived mesenchymal stem cells (ASCs) transplantation restored olfactory function in anosmic rats. Cell Ther Transplant 2019; 8(4): 84-90.

\section{Summary}

Olfactory dysfunction is a major challenge in medicine and there is no absolute treatment for anosmic patients. Adipose-derived mesenchymal stem cells (ASCs) are multipotent cells capable of differentiating into several cell lineages. The aim of present study was to assess effects of ASCs upon restoration of the olfactory function in anosmic rats.

\section{Materials and methods}

ASCs were isolated from the periuterine fat tissue of rats using collagenase type I. Anosmia was induced by intraperitoneal injection of 3-methylindole. Further on, $5 \times 10^{5}$ ASCs were transnasally transferred into the case group one day after the induction of anosmia. The control group included anosmic rats that were injected with culture media without ASCs. The olfactory function was evaluated weekly by a food-finding test. Olfactory neuroepithelium and bulb were harvested for histopathologic study at 4 and 8 weeks.

\section{Results}

Injection of ASCs caused about seven- and six-fold statistically significant reduction in the food-finding time in the case group of rats when compared to the control group tested, respectively, 4 and 8 weeks after injection of ASCs (P-value $=0.00$ and $=0.035$, respectively). Histopathological findings showed reconstruction of olfac-
Phone: +98 7132303687

Fax: +98 7132304952

E-mail: razmkhahm@sums.ac.ir, mrazmkhah2@gmail.com 


\section{Introduction}

Anosmia is a Greek word meaning the inability to perceive odor or loss of the sense of smell. It is a major olfactory disorder that greatly impairs an individual's quality of life. Several etiologies such as sinonasal disorders, including inflammatory disease like rhinosinusitis, nasal fracture, obstructive conditions of the upper respiratory tract, viral infections, brain trauma, and congenital and neurologic diseases may induce an olfactory dysfunction $[1,2]$. Olfactory disorders are also caused by reduction of olfactory receptor neurons in neuroepithelium and olfactory bulb area. The olfactory neuroepithelium covers the ethmoturbinate structure that contains the olfactory receptor neurons and is located in posterior region of the nasal cavity. Olfactory neuronal damage is mainly caused by loss of olfactory receptor neurons [3, $4,5]$, and regeneration of these receptors is associated with the function and presence of neural stem cells. Therefore, application of stem cells may have benefits for the treatment of olfactory dysfunction. In previous animal model studies, the olfactory function of anosmic mice was improved after transplantation of stem cells $[4,6]$. Such studies suggested a correlation between olfactory dysfunction and a decrease in the neuronal olfactory population, which can be replaced or repaired by using neural stem cells.

Mesenchymal stem cells (MSCs) are among the most interesting types of adult stem cells that could be isolated from different tissues, such as bone marrow, adipose tissue, umbilical cord blood, placental and amniotic fluid, and menstrual blood. These cells can be ex vivo manipulated and successfully applied for treatment clinical conditions, like coronary artery disease and vascular ischemia, bone and cartilage defects, and graft versus host disease (GVHD) [7, 8]. These effects are caused by the immunomodulatory properties of MSCs $[8,9]$, or differentiation ability of these cells into various mesodermal cell lineages [10-12]. Previous reports have also demonstrated the transdifferentiation ability of MSCs into endodermal and ectodermal lineages [13-15], including neural, epithelial, and islet-like cells. Adipose tissue is one of the most prominent sources of MSCs owing to the fact that this tissue is the most available and easy to harvest for extracting MSCs.

Hence, the aim of present study was to see how adipose-derived mesenchymal stem cells (ASCs) can contribute to the improvement of anosmia in rats.

\section{Materials and methods}

\section{Adipose-derived mesenchymal stem cells (ASCs) isolation, culture and characterization}

This case-control study in animal model was approved by the Research Animal Care Committee of Laboratory Animals of Shiraz University of Medical Sciences. Twenty-five Sprague Dawley female rats weighing 200 g each were divided into the case $(\mathrm{N}=15,10$ rats for autologous and 5 rats for allogenic transplantation) and control $(\mathrm{N}=10)$ groups. ASCs were isolated from periuterine fat tissue of the case group, washed with phosphate-buffered saline (PBS), sliced into small pieces, and then incubated with $0.2 \%$ collagenase type I (Gibco, USA) at $37^{\circ} \mathrm{C}$ in a shaker for two hours. Following routine cell centrifugation, the resulting pellet was incubated for 10 minutes in RBC lysis buffer and centrifuged again. The cell pellet was obtained for the separation of the stromal vascular fraction (SVF) using Ficoll-Paque density gradient (Biosera, UK). The SVF pellet was re-suspended in DMEM culture medium (Gibco, USA) containing 10\% fetal bovine serum (FBS, Gibco, USA) and 1\% penicillin/streptomycin (Biosera, UK). Non-adherent cells were discarded and adherent cells were cultured by changing the medium every three to four days and harvested on passage 3 for further experiments.

The third-passaged rat ASCs were examined by flow cytometry. Briefly, $5 \times 10^{5}$ trypsinized cells were separately stained with allophycocyanin (APC)-conjugated anti-rat CD90 or CD73 (BD Biosciences, USA) and fluorescein isothiocyanate (FITC)-conjugated anti-rat CD14 (BD Biosciences, USA). Isotype-matched irrelevant monoclonal antibodies (BD Biosciences, USA) were used to exclude non-specific staining of the cells (BD Biosciences, USA). Flow cytometric analysis was performed using FlowJo software version 7.6.

\section{Standard functional olfactory ability evaluation}

Before starting the experiments, olfactory function of the rats was evaluated, and then all the animals were put in the new environment, Maze apparatus (Suppl. Fig. 1), for adapting them to find food for 2 weeks. All the rats were fed routinely before the test, and then underwent fasting, except for water, for three days. Each rat was evaluated every 20 minutes for one hour to find the food, using the standard Maze test (food-finding test) [16]. The average time taken to find the food was between 12 and 19 seconds for all rats. Anosmia was induced by intraperitoneal injection of 3-methylindole (Sigma, USA) $(30 \mu \mathrm{g} / \mathrm{kg})$ which was applied elsewhere for induction of anosmia [17, 18]. On the next day, 500000 ASCs $/ 100 \mu$ l culture media were injected intranasally five times, $10 \mu \mathrm{l}$ in each nasal cavity every time. Autologous cells were used in 10 rats, and allogeneic, in five other rats. For the control group, culture medium without ASCs was similarly used for 10 rats. Evaluation of anosmia and the effects of injected ASCs were examined at four and eight weeks after induction of anosmia by means of standard Maze test and immunohistochemistry for olfactory bulb and olfactory neuroepithelium specimens.

\section{Histological study}

Rats were sacrificed with high dose of ketamine followed by harvesting of olfactory bulb and olfactory neuroepithelium and formalin fixation. The samples were then embedded in paraffin. Tissue sections were prepared, the slides were generated, and evaluation of the slides was done histologically using Hematoxylin staining.

\section{Statistical evaluation}

The data were analyzed with a Statistical Package for Social Science (SPSS) version 17 for windows (IBM, USA) using Student's t test to determine statistical significance between the control and case groups. Results were expressed as mean \pm SD and a p-value $<0.05$ was considered significant. 


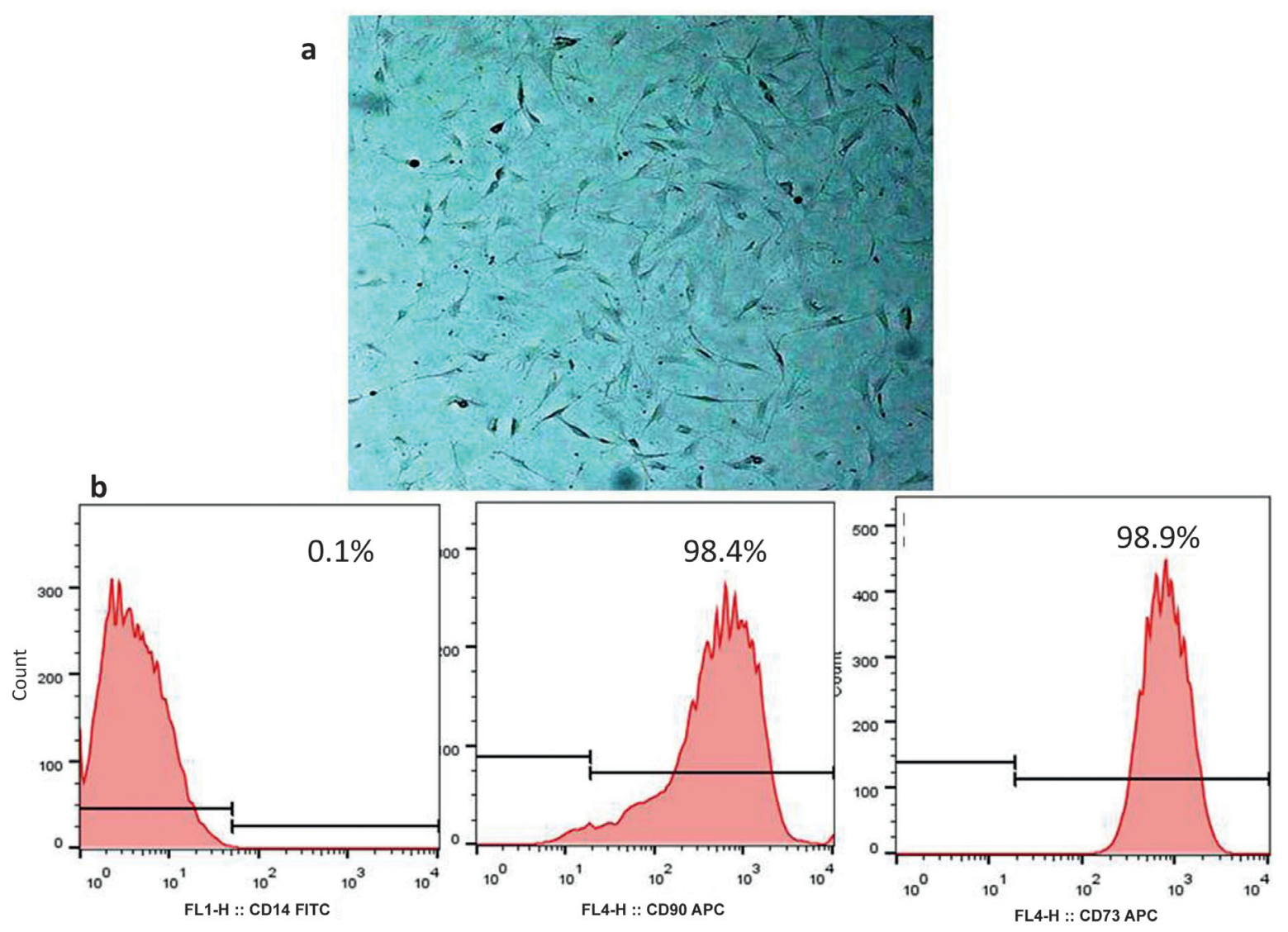

Figure 1. (a) Microscopic appearance of ASCs in culture in passage 3. Cultured ASCs were observed as spindle-shaped cell population. (b) Flow cytometric analysis of MSC-specific markers. Expression of CD73 and CD90 and absence of CD14 were shown on the surface of ASCs

\section{Results}

The average time for food finding was significantly different between the case and control groups

Adipose-derived mesenchymal stem cells were recognized by their spindle-shaped appearance in culture (Fig. 1a). These cells were positive for the expression of MSC specific markers, CD73 and CD90, but were negative for CD14 expression (Fig. 1b).

Olfactory function of rats was evaluated using the food-finding test. After four weeks, the mean \pm SD of the food-finding time were $13.8 \pm 4.1 \mathrm{sec}$., $14.6 \pm 8.6 \mathrm{sec}$., and $99.2 \pm 44.6 \mathrm{sec}$. in the rats after autologous injections, in rats subjected to allogeneic injections, and in anosmic controls, respectively. Thus, the injection of ASCs caused about a seven-fold statistically significant reduction in food-finding time in our case group of rats (P-value $=0.00$, Fig. 2). A six-fold statistically significant reduction in the food-finding time was observed in the case group of rats compared to the control group eight weeks after injection of ASCs. Accordingly, the food-finding time was $12.25 \pm 1.7 \mathrm{sec}$. in the case group, comparing with $73.6 \pm 29.3 \mathrm{sec}$. in the control group (P-value=0.035, Fig. 2). The mean food-finding time was not statistically different between the groups with autologous and allogeneic transplants (P-value $>0.05)$.

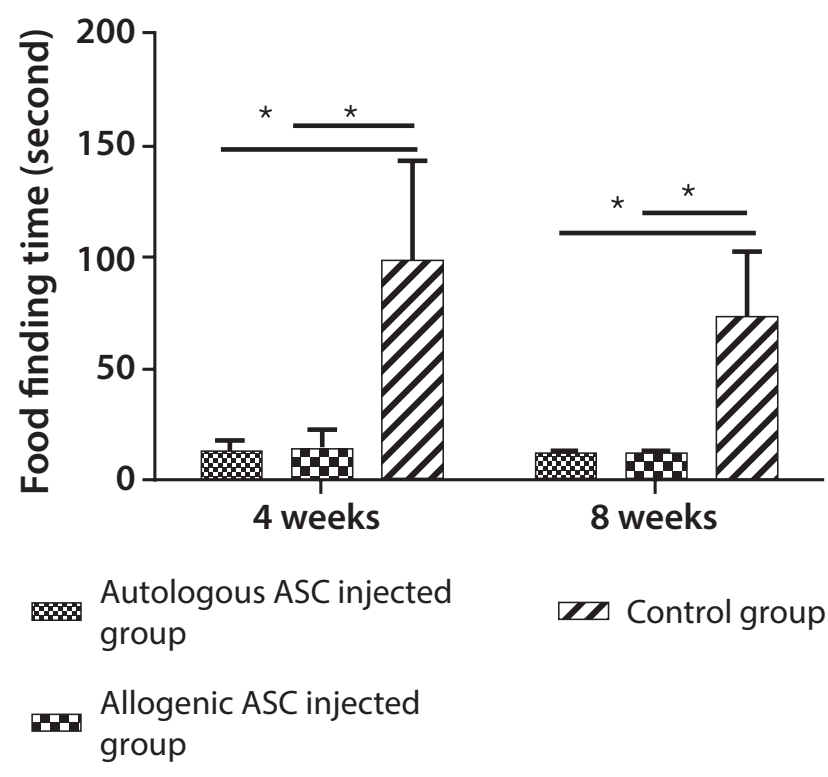

Figure 2. Comparison of the food finding mean time between the rats injected with autologous and allogeneic ASC (case group) and control group by 4 and 8 weeks after evaluation of olfactory function using the food-finding test. The differences between case and control groups were statistically significant. *: P-value $<0.05$ means a significant difference. 


\section{Histological evaluation}

Histological evaluations of the brain and ethmoturbinate of the stem-cell transplanted rats showed that olfactory neuroepithelium and olfactory bulbs were revealed, respectively, in 14 rats (93\%) (Fig. 3b) and nine rats (60\%) (Fig. 4b) out of 15 ASC-treated animals. No significant difference was found between autologous and allogeneic ASC-injected groups. In the control group, olfactory epithelium (Fig. 3a) and olfactory bulb (Fig. $4 \mathrm{a}$ ) were seen in five rats (50\%) and two rats (20\%) of all 10 control rats, respectively. As depicted in Fig. $3 \mathrm{a}$, olfactory epithelium in the control group showed severe infiltration with lymphocytes and neutrophils that penetrated the surface layers.

\section{Discussion}

MSCs are renowned mostly because of their unparalleled effects in regenerative medicine, which is caused by their outstanding ability to differentiate into various cell types, such as chondrocytes, osteocytes, and neural cells [7, 8, 14]. Recently, MSCs have been reported as promising therapeutic cell sources for restoring the function of neurons in neuro- degenerative disorders, including stroke, Batten disease, Parkinson's, Alzheimer's disease, and spinal cord injury $[19,20]$.

Olfactory disorders represent a common health problem, and their incidence has recently increased by $4-25 \%$ [21]. Impairment of sensory neural system is the main cause of olfactory dysfunction. Despite several therapeutic options, including medical and surgical procedures, the patients still suffer from recurrent anosmia. Since anosmia can be caused by degeneration of olfactory neuron receptors, Lee and colleagues suggested that transplantation of the neural stem cells stimulates regeneration of damaged olfactory cells [4]. Previous studies have demonstrated that other types of stem cells may effectively restore olfactory functions in various olfactory disorders. Jo et al. reported that the bone marrow mesenchymal stem cell (BMSCs) transplantation influences regeneration of olfactory epithelium and olfaction by expression of the nerve growth factor (NGF) and the brain-derived neurotrophic factor (BDNF) [22]. Ochi et al. reported migration of BMSCs to olfactory epithelium and higher engraftment rates in mice, and showed differentiation of these cells to premature olfactory receptor neurons in mice [23]. Human cord blood stem cells also showed promising results
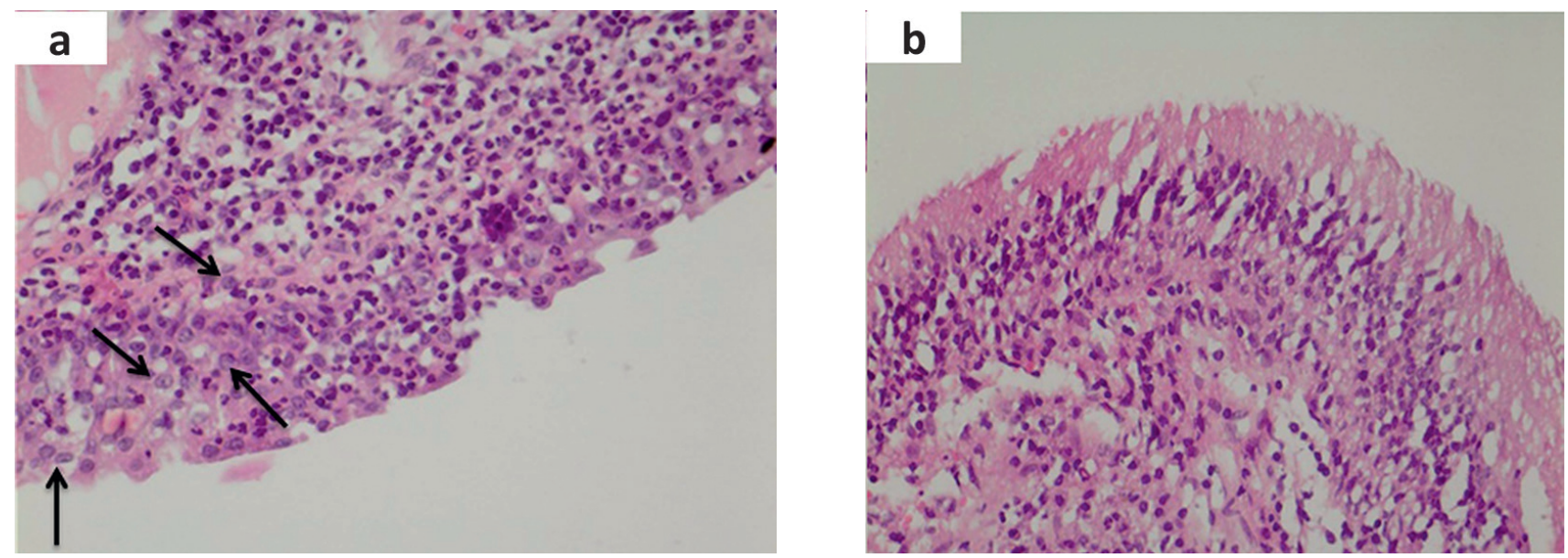

Figure 3. Olfactory epithelium in the non ASC-injected (control) and ASC-injected (case) groups. a: Olfactory epithelium in the control group with severe infiltration of lymphocytes and neutrophils penetrating surface layers. H\&E X250. b. OIfactory epithelium in the case group without inflammation. H\&E X250.
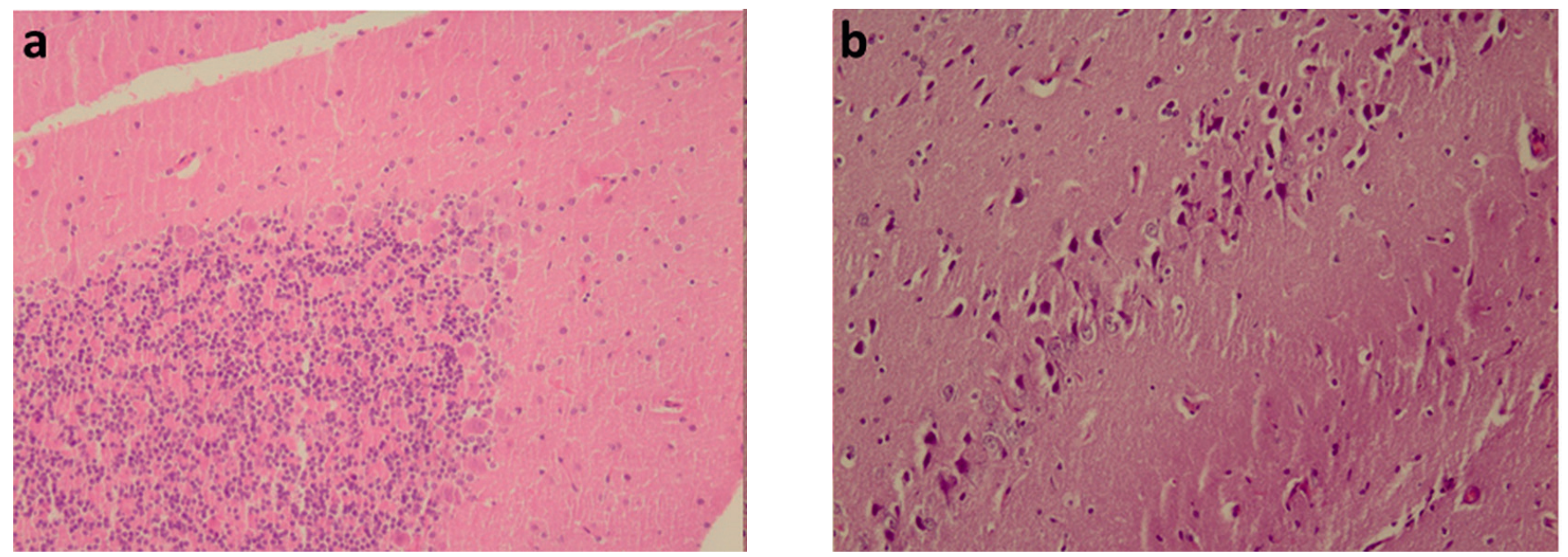

Figure 4. Olfactory bulb in the control group (a), and case group (b) with intact architecture and cells, however, without inflammation after ASC injection. H\&E X100. 
because it has been previously shown that BDNF-expressing hUCB-MSCs have great ability to differentiate into astrocytes and olfactory bulb in mice [24]. Furthermore, adipose tissue, an important source for stem cells, can be considered for differentiation towards a neuronal lineage and olfactory restoration [25-28]. As shown by Kokai and colleagues, ASCs may differentiate into different cell types, like neural stem cells [25]. Transplantation of ASCs in mice showed convincing results for restoration of neuroepithelium in the damaged olfactory region [29]. In the present study, anosmia was induced in a group of rats using 3-methylindole; then olfactory function of the anosmic rats was evaluated after injection of ASCs. The transplantation was performed either with allogeneic, or autologous ASCs, in order to compare any possible difference between the results, and to show whether autologous source of ASCs have any preference to allogeneic ones. Based on our results, a statistically significant reduction was observed in the food-finding time in anosmia-induced rats by four and eight weeks post injection of ASCs. Histological evaluation confirmed the effects of ASCs, since olfactory neuroepithelium and olfactory bulb of the brain and ethmoturbinate were detected in the stem cell-transplanted rats but not in the control group. No difference between autologous and allogeneic groups was found either in the mean duration of food-finding, or in histological evaluation. Accordingly, our findings are consistent with other reports showing the effects of stem cell transplantation in the recovery from anosmia, because the rats transplanted with ASCs after anosmia induction and destruction of the olfactory region, could find the food more rapidly than the animals from control group. This finding showed a faster functional recovery of olfactory system following ASCs treatment. Compared to other studies, the present survey was more preferential, due to safer and less invasive way for isolating stem cells and minimizing probable differentiation of the stem cells to other lineages by transnasal delivery of ASCs.

\section{Conclusion}

In summary, the present study provides the in vivo experimental evidence indicating that the administration of ASCs obtained from periuterine fat tissue may improve olfactory function. Studies with larger numbers of animals over longer periods of time can provide more confirmation of the efficacy of this approach as a therapeutic intervention for anosmic patients in the future. Adipose tissue represents an abundant and easily available cell source from which stem cells can be obtained by a less invasive method. Accordingly, this tissue may be considered the most promising alternative to the other sources of stem cells to these purposes.

\section{Acknowledgments}

This work was financially supported by grants from Shiraz University of Medical Sciences and Shiraz Institute for Cancer Research [Grant No. 91-01-01-5210 and ICR-100-504]. This research was done as a requirement for the special Ear, Nose, and Throat thesis defended by Dr. Zohreh Zandifar. We are grateful to Mr. Omid Koohi and Mr. Aziz Abbaspoor for doing the laboratory experiments and sampling.

The authors declare that they have no conflict of interest concerning this article.

\section{References}

1. Holbrook EH, Leopold DA. Anosmia: diagnosis and management. Curr Opin Otolaryngol Head Neck Surg. 2003;11(1):54-60.

2. Kern RC. Chronic sinusitis and anosmia: pathologic changes in the olfactory mucosa. Laryngoscope 2000; 110(7):1071-1077.

3. Franceschini V, Bettini S, Pifferi S, Rosellini A, Menini A, Saccardi R, Ognio E, Jeffery R, Poulsom R, Revoltella RP. Human cord blood CD133+ stem cells transplanted to nodscid mice provide conditions for regeneration of olfactory neuroepithelium after permanent damage induced by dichlobenil. Stem Cells. 2009;27(4):825-835.

4. Lee CH, Jeon SW, Seo BS, Mo JH, Jeon EH, Choi AR, Kim JW. Transplantation of neural stem cells in anosmic mice. Clin Exp Otorhinolaryngol. 2010; 3:84-90.

5. Pagano SF, Impagnatiello F, Girelli M, Cova L, Grioni E, Onofri M, Cavallaro M, Etteri S, Vitello F, Giombini S, Solero CL, Parati EA. Isolation and characterization of neural stem cells from the adult human olfactory bulb. Stem Cell 2000;18(4):295-300.

6. Kim JW, Hong SL, Lee CH, Jeon EH, Choi AR. Relationship between olfactory function and olfactory neuronal population in C57BL6 mice injected intraperitoneally with 3-methylindole. Otolaryngol Head Neck Surg. 2010;143:837842.

7. Murphy MB, Moncivais K, Caplan AI. Mesenchymal stem cells: environmentally responsive therapeutics for regenerative medicine. ExpMol Med. 2013;45:e54.

8. Kim N, Cho SG. Clinical applications of mesenchymal stem cells. Korean J Intern Med 2013; 28:387-402.

9. Beyer Nardi N, da Silva Meirelles L. Mesenchymal stem cells: isolation, in vitro expansion and characterization. Handb Exp Pharmacol. 2006; 174:249-282.

10. Chamberlain G, Fox J, Ashton B, Middleton J. Concise review: mesenchymal stem cells: their phenotype, differentiation capacity, immunological features, and potential for homing. Stem Cells 2007; 25: 2739-2749.

11. Mareschi K, Ferrero I, Rustichelli D, Aschero S, Gammaitoni L, Aglietta M, Madon E, Fagioli F. Expansion of mesenchymal stem cells isolated from pediatric and adult donor bone marrow. J Cell Biochem. 2006; 97(4):744-754.

12. Mitchell KE, Weiss ML, Mitchell BM, Martin P, Davis D, Morales L, Helwig B, Beerenstrauch M, Abou-Easa K, Hildreth T, Troyer D, Medicetty S. Matrix cells from Wharton's jelly form neurons and glia. Stem Cells 2003; 21:50-60.

13. Pokrywczynska M, Lewandowska MA, Krzyzanowska S, Jundzill A, Rasmus M, Warda K., Gagat M, Deptula A, Helmin-Basa A, Holysz M, Nowacki M, Buchholz L, Bodnar M, Marszalek A, Grzanka A, Jozwicki W, Michalkiewicz J, Drewa T. Transdifferentiation of Bone Marrow Mesenchymal Stem Cells into the Islet-Like Cells: the Role of Extracellular Matrix Proteins. Arch Immunol Ther Exp. 2015;63(5):377-384. 
14. Manochantr S, Marupanthorn K, Tantrawatpan C, Kheolamai $\mathrm{P}$. The expression of neurogenic markers after neuronal induction of chorion-derived mesenchymal stromal cells. Neurol Res. 2015;37:545-552.

15. Liang L, Wang J, Zhang Y, Shen Z, Zheng J, Li J, Su Z, Cai J, Jiang W, Sun M. Transdifferentiation of bone marrow-derived mesenchymal stem cells into salivary glandlike cells using a novel culture method. Biotechnol Lett. 2015;37(7):1505-1513.

16. Tolman EC, Nyswander DB. The reliability and validity of maze measures for rats. J Comp Psychol.1927;7:425-460.

17. Kim HY, Kim JH, Dhong HJ, Kim KR, Chung SK, Chung SC, Kang JM, Jung YG, Jang SY, Hong SD. Effects of statins on the recovery of olfactory function in a 3-methylindole-induced anosmia mouse model. Am J Rhinol Allergy. 2012;26(2):e81-84.

18. Peele DB, Allison SD, Bolon B, Prah JD, Jensen KF, Morgan KT. Functional deficits produced by 3-methylindole-induced olfactory mucosal damage revealed by a simple olfactory learning task. Toxicol Appl Pharmacol. 1991;107:191-202.

19. Kim SU, de Villis J. Stem cell-based therapy in neurological diseases: a review, J Neurosci Res 2009;87:2183-2200.

20. Ul Hassan A, Hassan G, Rasool Z. Role of stem cells in treatment of neurological disorder. Int J Health Sci (Qassim). 2009;3:227-233.

21. Dalton P. Olfaction and anosmia in rhinosinusitis. Curr Allergy Asthma Rep. 2004; 4(3):230-236.

22. Jo H, Jung M, Seo DJ, Park DJ. The effect of rat bone marrow derived mesenchymal stem cells transplantation for restoration of olfactory disorder. Biochem Biophys Res Commun. 2015;467:395-399.

23. Ochi N, Doi K, Uranagase M, Nishikawa T, Katsunuma S, Nibu K. Bone marrow stem cell transplantation to olfactory epithelium. Ann Otol Rhinol Laryngol. 2010;119:535-540.

24. Lim JY, Park SI, Kim SM, Jun JA, Oh JH, Ryu CH, Jeong $\mathrm{CH}$, Park SH, Park SA, Oh W, Chang JW, Jeun SS. Neural differentiation of brain-derived neurotrophic factor-expressing human umbilical cord blood-derived mesenchymal stem cells in culture via TrkB-mediated ERK and $\beta$-catenin phosphorylation and following transplantation into the developing brain. Cell Transplant. 2011;20(11-12):1855-1866.

25. Kokai LE, Rubin JP, Marra KG. The potential of adipose-derived adult stem cells as a source of neuronal progenitor cells. Plast Reconstr Surg. 2005;116:1453-1460.

26. Goudarzi F, Tayebinia H, Karimi J, Habibitabar E, Khodadadi I. Calcium: A novel and efficient inducer of differentiation of adipose-derived stem cells into neuron-like cells. J Cell Physiol. 2018; 233(11):8940-8951.

27. Moon MY, Kim HJ, Choi BY, Sohn M, Chung TN, Suh SW. Zinc Promotes Adipose-Derived Mesenchymal Stem Cell Proliferation and Differentiation towards a Neuronal Fate. Stem Cells Int. 2018;2018:5736535.
28. Fesharaki M, Razavi S, Ghasemi-Mobarakeh L, Behjati M, Yarahmadian R, Kazemi M, Hejazi H. Differentiation of human scalp adipose-derived mesenchymal stem cells into mature neural cells on electrospun nanofibrous scaffolds for nerve tissue engineering applications. Cell J. 2018; 20(2): 168-176.

29. Franceschini V, Bettini S, Pifferi S, Menini A, Siciliano G, Ognio E, Brini AT, Di Oto E, Revoltella RP. Transplanted human adipose tissue-derived stem cells engraft and induce regeneration in mice olfactory neuroepithelium in response to dichlobenilsubministration. Chem Senses. 2014;39:617-629. 


\title{
| Трансплантация жировых мезенхимальных стволо- вых клеток (жМСК) восстанавливает обонятельную функцию у крыс с аносмией
}

\author{
Биджан Хадеми ${ }^{1,2}$, Зохре Зандифар ${ }^{2}$, Ахмад Монабати ${ }^{3}$, Нушафарин Ченари ${ }^{4}$, Аббас Гадери ${ }^{4,5}$, Мабубе Размха ${ }^{4}$ \\ ${ }^{1}$ Научный центр ЛОР-хирургии области головы и шеи, Ширазский университет медицинских наук, Шираз, Иран \\ 2 Департамент оториноларингологии, Ширазский медицинский университет, Шираз, Иран \\ 3 Департамент патологии, Школа медицины, Ширазский медицинский университет, Шираз, Иран \\ ${ }^{4}$ Ширазский институт раковых исследований, Школа медицины, Ширазский медицинский университет, Шираз, Иран \\ 5 Департамент иммунологии, Школа медицины, Ширазский медицинский университет, Шираз, Иран
}

\section{Резюме}

Нарушения обонятельной функции являются большой проблемой медицины, и нет радикального лечения больных с аносмией. Мезенхимные стволовые клетки, полученные из жировой ткани (АМСК) являются мультипонтентными клетками, способными к дифференцировке в несколько клеточных ростков. Целью настоящего исследования была оценка эффектов АМСК на восстановление обонятельной функции у крыс с аносмией.

\section{Материалы и методы}

АМСК изолировали из околоматочной жировой ткани крыс с применением коллагеназы типа 1. Аносмию индуцировали путем интраперитонеального введения 3-метилиндола. Затем через 1 сут. после индукции аносмии, вводили $5 \times 10^{5}$ АМСК трансназально животным опытной группы. В контрольной группе были крысы с аносмией, которым вводили культуральную среду без АМСК. Обонятельную функцию оценивали еженедельно с помощью теста нахождения пищи. Обонятельный нейроэпителий и луковицу забирали для гистопатологического исследования в сроки 4 и 8 недель.

\section{Результаты}

После инъекции АМСК наблюдалось примерно 6-7 кратное снижение времени нахождения пищи в опытной группе крыс по сравнению с контрольной группой. Различие было достоверным при $\mathrm{P}=0,00$ и $\mathrm{P}=0,035$, соответственно, через 4 и 8 недель после инъекции АМСК. Результаты гистопатологического исследования показали реконструкцию обонятельного нейроэпителия в 93\% случаев в опытной группе, и в 50\% - у контрольных крыс. Обонятельная луковица выявлялась у $60 \%$ крыс в опыте, по сравнению с $20 \%$ в контроле.

\section{Выводы}

Полученные нами результаты показывают, что регенерация обонятельного эпителия может быть ускорена при использовании локального введения АМСК. Эти данные предполагают, что АМСК в будущем могут быть перспективным источником лечения дисфункции обоняния.

\section{Ключевые слова}

Аносмия, экспериментальная, мезенхимные стволовые клетки, жировая ткань, дифференцировка, нейрональные клетки. 